\title{
The Analysis of Gear Shift Indicator Test Results
}

Ivan A. Blagojević

Assistant Professor University of Belgrade Faculty of Mechanical Engineering

\section{Dragan D. Stamenković \\ Teaching Assistant University of Belgrade \\ Faculty of Mechanical Engineering}

\author{
Branislav B. Rakićević \\ Full Professor \\ University of Belgrade \\ Faculty of Mechanical Engineering
}

The results of tests according to Regulation (EU) No 65/2012 regarding gear shift indicators on 59 different vehicles are analyzed. Primary parameters were the vehicle speeds at which the gear shift is indicated through gear shift indicator (GSI), and based on their deviation from standard gear shift points defined for type I emission tests in UNECE Regulation No 83, it is concluded that standard gear shift points need to be revised. Relative fuel savings when shifting according to GSI instructions compared to standard gear shift points were analyzed (average 5.2\%, maximum 19.9\%). It is also shown that automaatic transmission gave bigger fuel saving when manual mode is used according to GSI, compared to manual transmission, also used with GSI. It is concluded that statistical analysis on how drivers follow GSI instructions may be used to improve current test procedures for GSI efficiency, fuel consumption measurement and emission tests.

Keywords: gear shift indicator, Regulation (EU) No 65/2012, fuel consumption, gear shift points.

\section{INTRODUCTION}

Limited oil reserves and growing pollution caused by ever-increasing number of vehicles, together with legislation dealing with the area, force the manufacturers to constantly reduce fuel consumption and engine emission in their vehicles. One of the complementary measures, as required by Regulation (EC) No 661/2009, is the fitment of gear shift indicators (GSIs) on all vehicles of category M1, fitted with manual gearbox, with a reference mass not exceeding $2610 \mathrm{~kg}$ or type-approval is extended in accordance with Article 2(2) of Regulation (EC) No 715/2007. The aim of GSI is to provide a visual indication, advising driver to change gear when the GSI indicates they should, thus reducing fuel consumption. Regulation (EC) No 661/2009 requires the technical details of its provisions on GSI to be defined by implementing legislation, while Regulation (EU) No 65/2012 [1] sets out the specific procedure, tests and requirements for such type-approval of GSI. The results of such tests are collected and analyzed in this study for $59 \mathrm{M} 1$ category vehicles of different makes. Some of the vehicles are of the same type, but equipped with different engine and transmission, making the analysis of the effect of Regulation (EU) No 65/2012 and GSIs more applicable.

\section{GSI AND CHARACTERISTIC PARAMETERS}

Previous studies [2,3] point out with arguments that manual gear shifting may be considered as an automatic process performed routinely, but only for experienced

Received: July 2016, Accepted: September 2016

Correspondence to: Dr Ivan Blagojević

Faculty of Mechanical Engineering,

Kraljice Marije 16, 11120 Belgrade 35, Serbia

E-mail: iblagojevic@mas.bg.ac.rs

doi:10.5937/fmet1704585B

(C) Faculty of Mechanical Engineering, Belgrade. All rights reserved drivers. On the other hand, for drivers who have just been granted driving license this process requires a mental effort. Automation is therefore achieved through experience which is mostly independently acquired by a driver.

In addition, by detailed analysis of the relation between driver's behavior and fuel consumption [4-6] it was proved that those elements of driver's behavior, related to gear selection, vehicle speed and acceleration/deceleration have the largest influence on fuel consumption. The fuel consumption at the same average vehicle speed can be increased up to $20 \%$ only due to difference in the manner of gear shifting [7].

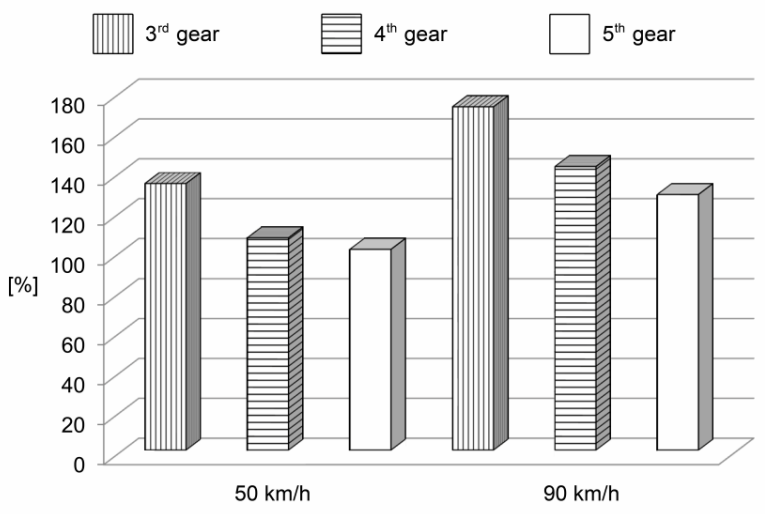

Figure 1. Fuel consumption compared to $50 \mathrm{~km} / \mathrm{h}$ in 5 th gear [8]

Very picturesque overview of the effect of gear selection on fuel consumption at some vehicle speeds can be observed in the shown graph (Figure 1) as the result of investigations carried out by Volkswagen on a passenger car [8]. The increase of fuel consumption in percentages when driving in third and fourth gear is shown relative to the fuel consumption when driving in fifth gear at the speed of $50 \mathrm{~km} / \mathrm{h}$ and $90 \mathrm{~km} / \mathrm{h}$ (fuel consumption in fifth gear at the speed of $50 \mathrm{~km} / \mathrm{h}$ was 
accepted as the reference value - 100\%). When differences in fuel consumption in different gears at the same conditions are perceived, it can be concluded that significant savings in fuel consumption can be achieved by adequate gear selection, which has both large economic and environmental significance.

Beside the tests conducted by the manufacturers, there were only a few studies that have tried to find a solution for resolving the problem [9-11]. Some manufacturers interested in improvement of fuel economy by proper gear shifting came up with a new device, which unequivocally indicates to drivers when to shift gear, up or down, to reduce fuel consumption for the same driving conditions. Commission Regulation (EU) No 65/2012, implementing Regulation (EC) No $661 / 2009$ of the European Parliament and of the Council regarding gear shift indicators, defines special requirements for vehicles equipped with GSI. It sets functional requirements for GSI (applicable to all manual modes):

1) the GSI shall suggest changing the gear when the fuel consumption with the suggested gear is estimated to be lower than the current one giving consideration to emission and safe operation requirements;

2) the GSI shall be designed to encourage an optimized fuel efficient driving style under reasonably foreseeable driving conditions.

Its main purpose is to minimize the fuel consumption of the vehicle when the driver follows its indication. However, regulated tailpipe emissions shall not be disproportionately increased with respect to the initial state when following the indication of the GSI.

The most important requirement for the purpose of this research, set by Regulation (EU) No 65/2012, is determination of fuel economy impact of GSI recommended gear shift points according to the following data:

- Vehicle speeds at which GSI recommends shifting up gears. $V_{\text {GSI }}^{n}$ shall denote the average speed at which the GSI recommends shifting up from gear $n(n=1,2, \ldots, \# g)$ into gear $n+1$, determined from 3 tests, where \# $g$ shall denote the vehicle's number of forward gears. For this purpose, only GSI shift instructions in the phase before the maximum speed is reached are taken into account and any GSI instruction during the deceleration is ignored;

- The values of $F C^{n}{ }_{i}$ of the fuel consumption speed curve. $F C^{n}{ }_{i}$ shall denote the fuel consumption in terms of $\mathrm{kg} / \mathrm{h}$ when the vehicle is driven with the constant vehicle speed $v_{i}=i \times 5 \mathrm{~km} / \mathrm{h}-2.5 \mathrm{~km} / \mathrm{h}$ (where $i$ is positive integer number) in the gear $n$. These fuel consumption values shall be determined under identical ambient conditions corresponding to a realistic driving situation that may be defined by the vehicle manufacturer, either by a physical test or by an appropriate calculation model agreed between the approval authority and the manufacturer.

The values $F C_{\mathrm{GSI}}, F C_{\text {std }}$ and $F C_{\text {rel.save }}$ are calculated according to the fuel consumption model.

\subsection{Fuel consumption model}

$F C_{\mathrm{GSI}}$ shall denote the fuel consumption of the vehicle when the driver follows the advice of the GSI:

$$
F C^{\mathrm{GSI}}{ }_{i}=F C^{n}{ }_{i},
$$

where $V^{n-1}{ }_{\mathrm{GSI}} \leq v_{i}<V_{\mathrm{GSI}}^{n}$ (for $n=1, \ldots, \# g$ ) and $F C^{\mathrm{GSI}}=0$ if $v_{i} \geq V_{\mathrm{GSI}}^{\# g}$.

$$
F C_{\mathrm{GSI}}=\sum_{i=1}^{28} \frac{P_{i} \cdot F C_{i}^{\mathrm{GSI}}}{100} .
$$

$F C_{\text {std }}$ shall denote the fuel consumption of the vehicle when standard gear shift points are used:

$$
F C^{\mathrm{std}}{ }_{i}=F C^{n}{ }_{i}
$$

where $V^{n-1}{ }_{\text {std }} \leq v_{\mathrm{i}}<V^{n}$ std $\left(\right.$ for $n=1, \ldots, \# g$ ) and $F C^{\text {std }}{ }_{i}=0$ if $v_{i} \geq V_{\mathrm{GSI}}^{\# g}$.

$$
F C_{\text {std }}=\sum_{i=1}^{28} \frac{P_{i} \cdot F C_{i}^{\mathrm{std}}}{100} .
$$

The relative saving of fuel consumption by following the advice of the GSI of the model is calculated as:

$$
F C_{\text {rel.save }}=\left(1-F C_{\mathrm{GSI}} / F C_{\mathrm{std}}\right) \cdot 100 \% .
$$

The vehicle speed distribution used for the calculation is defined by Regulation (EU) No 65/2012 by the probabilities $P_{i}$ (shown in Figure 2) for a vehicle speed to be $v$, where $v_{i}-2,5 \mathrm{~km} / \mathrm{h}<v \leq v_{i}+2,5 \mathrm{~km} / \mathrm{h}(i$ $=1, \ldots, 28)$. Where the maximum speed of the vehicle corresponds to step $i$ and $i<28$, the values of $P_{i+1}$ to $P_{28}$ shall be added to $P_{i}$.

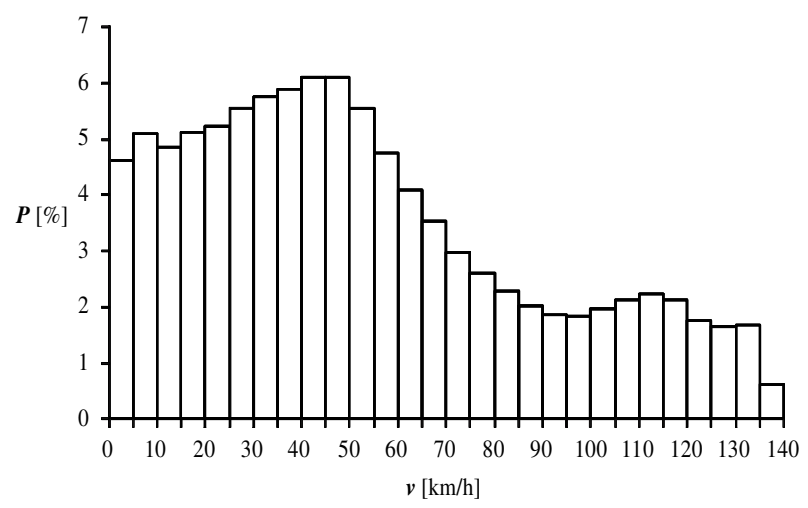

Figure 2. Probability $\boldsymbol{P}_{i}$ for vehicle speed distribution during test

Standard gear shift points $V_{\text {std }}^{n}$ shall denote the speed at which a typical driver is assumed to shift up from gear $n$ to gear $n+1$ without GSI recommendation. Based on the gear shift points defined in type I emission test (Annex 4a of UNECE Regulation No 83, 05 series of amendments) the following standard gear shift speeds are defined: $V_{\text {std }}^{0}$ $=0 \mathrm{~km} / \mathrm{h}, V_{\text {std }}^{1}=15 \mathrm{~km} / \mathrm{h}, V_{\text {std }}^{2}=35 \mathrm{~km} / \mathrm{h}, V_{\text {std }}^{3}=50$ $\mathrm{km} / \mathrm{h}, V_{\text {std }}^{4}=70 \mathrm{~km} / \mathrm{h}, V_{\text {std }}^{5}=90 \mathrm{~km} / \mathrm{h}, V_{\text {std }}^{6}=110 \mathrm{~km} / \mathrm{h}$, $V_{\text {std }}^{7}=130 \mathrm{~km} / \mathrm{h}$ and $V_{\text {std }}^{8}=V_{\text {GSI }}^{\# g} \mathrm{~km} / \mathrm{h}$.

\section{TESTED VEHICLES}

The present research includes the results obtained by testing a group of $59 \mathrm{M} 1$ category vehicles according to 
the requirements of Annex 1 of Commission Regulation (EU) No 65/2012. Nine vehicle makes are marked with numbers from 1 to 9 for confidentiality. For the same reason, the vehicle type is marked with the segment marking according to the Table 1 .

Table 1. Vehicle type marking according to market segment

\begin{tabular}{|c|l|}
\hline A & mini cars \\
\hline B & small cars \\
\hline C & medium cars \\
\hline D & large cars \\
\hline E & executive cars \\
\hline F & luxury cars \\
\hline S & sports coupés \\
\hline M & multi purpose cars \\
\hline J & sport utility cars (including off-road vehicles) \\
\hline
\end{tabular}

If there is more than one type in the same segment of the same make, they are distinguished using the numeric indices, where higher number indicates larger vehicle (e.g. $2 \mathrm{~J}_{1}$ represents small SUV, while $2 \mathrm{~J}_{2}$ represents large SUV). Table 2 shows all 59 vehicles with engine working principle (positive ignition - Otto / with or without Turbo compressor, compression ignition Diesel), engine capacity, maximum engine net power, type of gearbox with number of gears (first place indicates the number of gears, while latter 2 indicate transmission type: MT - manual transmission, AT automatic transmission) and approximate mass of the vehicle in running order.

As can be seen from the Table 2, there are vehicles of the same make and type, but with different engines different working principle, different power (including the cases when the capacity is the same and when the capacity is different) and different transmission, all to make the analysis more comprehensive.

Engine capacity ranges from $998 \mathrm{~cm}^{3}$ to $4951 \mathrm{~cm}^{3}$. Maximum net power ranges from $45 \mathrm{~kW}$ to $426 \mathrm{~kW}$. The analysis also covers the vehicles with automatic transmission (hydro-mechanical, DSG and even CVT with discrete gear ratios in manual mode), in which GSI indicates the shift only in manual mode, where the driver makes decisions instead of the transmission control unit.

\section{THE ANALYSIS OF TEST RESULTS}

As mentioned before, for the purpose of this study, following manufacturers' declared values are collected and analyzed: the values of vehicle speed at which GSI recommends shifting gear up - $V_{\mathrm{GSI}}^{n}$ and the values $F C_{\mathrm{GSI}}, F C_{\text {std }}$ and $F C_{\text {rel.save }}$ obtained according to the Annex I of Regulation (EU) No 65/2012.

The analysis of vehicle speeds at which GSI recommends shifting gears up ( $\left.V_{\text {GSI }}^{n}\right)$ for all 59 vehicles and a comparison with standard gear shift points $V_{\text {std }}^{n}$ defined in type I emission test provided some very interesting results. Table 3 shows average values

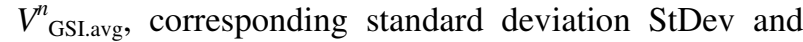
minimum $\left(V_{\text {GSI.min }}^{n}\right)$ and maximum $\left(V_{\text {GSI.max }}^{n}\right)$ speed values registered in the sample given in Table 2.
Table 2. Specification of tested vehicles

\begin{tabular}{|c|c|c|c|c|}
\hline $\begin{array}{c}\text { Make } \\
\text { and type }\end{array}$ & $\begin{array}{c}\text { Engine } \\
\text { working } \\
\text { principle }\end{array}$ & $\begin{array}{c}\text { Engine capacity } \\
{\left[\mathrm{cm}^{3}\right] / \text { max net }} \\
\text { power }[\mathrm{kW}]\end{array}$ & $\begin{array}{c}\text { Number of } \\
\text { gears, type of } \\
\text { gearbox }\end{array}$ & $\begin{array}{c}\text { Mass } \\
{[\mathrm{kg}]}\end{array}$ \\
\hline $1 \mathrm{C}$ & Otto & $1598 / 97$ & $6 \mathrm{MT}$ & 1275 \\
\hline $1 \mathrm{C}$ & Otto & $1329 / 73$ & $6 \mathrm{MT}$ & 1225 \\
\hline $1 \mathrm{C}$ & Otto/Turbo & $1197 / 85$ & $6 \mathrm{MT}$ & 1225 \\
\hline $1 \mathrm{C}$ & Diesel & $1598 / 82$ & $6 \mathrm{MT}$ & 1395 \\
\hline $1 \mathrm{C}$ & Diesel & $1364 / 66$ & $6 \mathrm{MT}$ & 1375 \\
\hline $1 \mathrm{M}$ & Diesel & $2231 / 130$ & 6AT & 1660 \\
\hline $1 \mathrm{M}$ & Diesel & $2231 / 130$ & 6MT & 1660 \\
\hline $1 \mathrm{M}$ & Diesel & 1998/91 & $6 \mathrm{MT}$ & 1600 \\
\hline 1D & Diesel & $2231 / 130$ & $6 \mathrm{MT}$ & 1645 \\
\hline 1D & Diesel & $1995 / 105$ & $6 \mathrm{MT}$ & 1580 \\
\hline $1 \mathrm{~J}$ & Diesel & $2231 / 110$ & $6 \mathrm{MT}$ & 1720 \\
\hline $2 \mathrm{~A}$ & Otto & $998 / 48,5$ & 5MT & 1008 \\
\hline $2 \mathrm{~A}$ & Otto & $998 / 48,5$ & $4 \mathrm{AT}$ & 1036 \\
\hline $2 \mathrm{~B}$ & Otto & $1368 / 74$ & $4 \mathrm{AT}$ & 1100 \\
\hline $2 \mathrm{C}$ & Otto & $1368 / 74$ & $6 \mathrm{MT}$ & 1247 \\
\hline $2 \mathrm{C}$ & Otto & $1591 / 99$ & $6 \mathrm{MT}$ & 1280 \\
\hline $2 \mathrm{C}$ & Otto & $1591 / 99$ & 6AT & 1300 \\
\hline $2 \mathrm{~J}_{1}$ & Diesel & $1685 / 85$ & $6 \mathrm{MT}$ & 1550 \\
\hline $2 \mathrm{~J}_{1}$ & Diesel & $1995 / 100$ & $6 \mathrm{MT}$ & 1600 \\
\hline $2 \mathrm{~J}_{1}$ & Diesel & $1995 / 100$ & $6 \mathrm{AT}$ & 1630 \\
\hline $2 J_{1}$ & Otto & $1591 / 97$ & $6 \mathrm{MT}$ & 1420 \\
\hline $2 \mathrm{~J}_{1}$ & Otto & $1591 / 97$ & $6 \mathrm{AT}$ & 1440 \\
\hline $2 \mathrm{~J}_{1}$ & Otto/Turbo & $1591 / 130$ & $6 \mathrm{MT}$ & 1450 \\
\hline $2 \mathbf{J}_{1}$ & Otto/Turbo & $1591 / 130$ & 7AT & 1450 \\
\hline $2 \mathrm{~J}_{1}$ & Otto & $1999 / 114$ & $6 \mathrm{MT}$ & 1500 \\
\hline $2 \mathrm{~J}_{1}$ & Otto & $1999 / 114$ & 6AT & 1530 \\
\hline $2 \mathrm{~J}_{2}$ & Otto & $2359 / 138$ & $6 \mathrm{MT}$ & 1900 \\
\hline $2 \mathrm{~J}_{2}$ & Otto & $2359 / 138$ & 6AT & 1930 \\
\hline $2 \mathrm{~J}_{2}$ & Diesel & $1995 / 136$ & $6 \mathrm{MT}$ & 1930 \\
\hline $2 \mathrm{~J}_{2}$ & Diesel & $2199 / 147$ & 6AT & 2000 \\
\hline $3 \mathrm{D}(\mathrm{AA})$ & Otto & $2498 / 129$ & $6 \mathrm{MT}$ & 1520 \\
\hline $3 \mathrm{D}(\mathrm{AC})$ & Otto & $2498 / 129$ & $6 \mathrm{MT}$ & 1575 \\
\hline $3 \mathrm{D}(\mathrm{AC})$ & Diesel & $1998 / 110$ & $6 \mathrm{MT}$ & 1612 \\
\hline 4B & Otto & $998 / 74$ & $5 \mathrm{MT}$ & 1123 \\
\hline $4 \mathrm{~B}$ & Otto & $998 / 74$ & 6AT & 1123 \\
\hline $4 \mathrm{~S}$ & Otto & $2261 / 233$ & $6 \mathrm{MT}$ & 1695 \\
\hline $4 \mathrm{~S}$ & Otto & $2261 / 233$ & 6AT & 1692 \\
\hline $4 \mathrm{~S}$ & Otto & $4951 / 310$ & $6 \mathrm{MT}$ & 1726 \\
\hline $4 \mathrm{~S}$ & Otto & $4951 / 310$ & $6 \mathrm{AT}$ & 1734 \\
\hline $5 \mathrm{E}$ & Otto & $1997 / 135$ & $6 \mathrm{MT}$ & 1500 \\
\hline $6 \mathrm{~S}$ & Otto & $3993 / 373$ & $8 \mathrm{AT}$ & 2370 \\
\hline $6 \mathrm{~S}$ & Otto & $3993 / 426$ & $8 \mathrm{AT}$ & 2270 \\
\hline $7 E$ & Diesel & $1999 / 120$ & $6 \mathrm{MT}$ & 1587 \\
\hline $7 E$ & Diesel & $1999 / 120$ & $8 \mathrm{AT}$ & 1608 \\
\hline $7 \mathrm{E}$ & Diesel & $1999 / 132$ & $6 \mathrm{MT}$ & 1647 \\
\hline $7 \mathrm{E}$ & Diesel & $1999 / 132$ & $8 \mathrm{AT}$ & 1661 \\
\hline $7 \mathrm{E}$ & Otto & $1999 / 177$ & $8 \mathrm{AT}$ & 1638 \\
\hline $7 E$ & Otto & $2995 / 250$ & $8 \mathrm{AT}$ & 1744 \\
\hline $8 \mathrm{C}$ & Diesel & $1796 / 80$ & 7AT & 1475 \\
\hline $8 \mathrm{C}$ & Diesel & $1796 / 100$ & $6 \mathrm{MT}$ & 1475 \\
\hline $8 \mathrm{C}$ & Otto & $1595 / 90$ & 7AT & 1395 \\
\hline $8 \mathrm{C}$ & Otto & $1595 / 115$ & $6 \mathrm{MT}$ & 1395 \\
\hline $8 \mathrm{E}$ & Otto & $1991 / 135$ & $6 \mathrm{MT}$ & 1615 \\
\hline $8 \mathrm{E}$ & Otto & $1991 / 135$ & 7AT & 1655 \\
\hline $8 \mathrm{E}$ & Diesel & $2143 / 100$ & $7 \mathrm{AT}$ & 1700 \\
\hline $8 \mathrm{~F}$ & Diesel & $2143 / 100$ & $6 \mathrm{MT}$ & 1680 \\
\hline $8 \mathrm{~F}$ & Diesel & $2987 / 185$ & 9AT & 1800 \\
\hline $9 \mathrm{~A}$ & Otto & $999 / 45$ & 5MT & 830 \\
\hline $9 \mathrm{~A}$ & Otto & $999 / 72$ & 5MT & 880 \\
\hline
\end{tabular}

It can be concluded that there are significant differences between standard gear shift points defined by 
type I emission test and average shift points prescribed by GSIs, except the shift from $1^{\text {st }}$ to $2^{\text {nd }}$ gear. For shift from $4^{\text {th }}$ to $5^{\text {th }}$ the difference is higher than $10 \mathrm{~km} / \mathrm{h}$, while for shift from $6^{\text {th }}$ to $7^{\text {th }}$ and $7^{\text {th }}$ to $8^{\text {th }}$ differences rise to over $20 \mathrm{~km} / \mathrm{h}$, resulting in significant difference in fuel consumption. Smaller differences ranging from 5 to $6 \mathrm{~km} / \mathrm{h}$ (for shifting from $3^{\text {rd }}$ to $4^{\text {th }}$ and from $5^{\text {th }}$ in $6^{\text {th }}$ ) cannot be neglected, having in mind the dissipation of the results reflected in maximum and minimum values. It is obvious and quite logical that the dissipation of the results grows with higher initial gear in shift. The highest deviations from average values $V_{\text {GSI.avg }}^{n}$ are recorded in vehicles with transmission having more than 6 gears, where increase in the number of gears results in lower values of speed at gear shift points. The removal of these extremes will not result in significant change in the contents of Table 3 , so it is not shown.

It is interesting to divide the obtained results in three groups: MT with up to 6 gears; AT with up to 6 gears and AT with 8 gears, as showed in Table 3 .

It can be said here that average speed values indicated for shifting by GSI for MT and AT with maximum 6 gears (which are most common) are very close to each other, except the shift from $4^{\text {th }}$ to $5^{\text {th }}$ where the difference reaches $5.6 \mathrm{~km} / \mathrm{h}$.

Greater part of GSIs installed in vehicles with same engine indicated gear change at lower speeds for AT, but it cannot be regarded as a rule, since there are opposite cases.

It is expected for GSIs installed in vehicles of the same type to indicate gear shift at lower speeds for more powerful engines, and it was confirmed in most of the cases. However, for two vehicle types from $S$ segment and one from E segment that wasn't the case. It should be noted here that GSI must be led only by fuel consumption, and not by vehicle performance.

By considering the number of speed values in described fuel consumption model for calculating $F C_{\text {std }}$ and $F C_{\mathrm{GSI}}$ at which the suggested gear is different from the standard one, it can be seen that it ranges from 1 to 25 and more than 9 in average. So, for the whole set of discrete speed values with the increment of $5 \mathrm{~km} / \mathrm{h}$ described in the model and used for fuel consumption calculation, above 9 of them in average are reached in different gear when indicated as GSI compared to standard shift points. Not one GSI in the analysis completely matched the standard gear shift points. If we isolate only the vehicles equipped with MT (with up to 6 gears), average number of values of speed reached in different gear compared to standard shift pattern is 7 . This number rise over 12 for vehicles with AT, which can be explained by the fact that there were vehicles in the analysis with more than 6 gears. By ignoring such vehicles, the number drops from above 12 to 8 . In each case, the increase in number of gears (which is the trend in modern vehicles) results in raising the number of speed values at which indicated gear deviate from the standard to 17 and even 25.

The whole issue can be regarded through the data on relative fuel savings $F C_{\text {rel.save }}$ stated in the reports on tests conducted by manufacturers showing the effects in fuel savings when using GSI compared to standard gear shift points. Average savings for all 59 vehicles is 5.2\% with highly dissipated results (min 0\%, $\max 19.9 \%$ ). The conclusion is that the higher the difference in gear shift speed suggested by GSI compared to standard shift points is, the bigger are the savings.

The same can be concluded through the number of discrete speed values characterized by the difference in GSI indication and standard shift points. The higher this number is, the bigger are the savings. This is most noticeable in vehicles equipped with MT with more than 6 gears, which is logical. For that reason, the biggest values of $F C_{\text {rel.save }}$ are recorded in those vehicles. When these vehicles are excluded from the analysis, average savings are $3.66 \%(\max 11.2 \%)$, which cannot be neglected. In this narrowed set of vehicles, AT gave bigger fuel saving $(4.71 \%)$ when used according to GSI, compared to MT used with GSI (3.25\%).

Table 3. Average values, corresponding standard deviation values and minimal and maximal speed values

\begin{tabular}{|c|c|c|c|c|c|c|c|c|}
\hline & & $\mathrm{n}=1,1 \rightarrow 2$ & $\mathrm{n}=2,2 \rightarrow 3$ & $\mathrm{n}=3,3 \rightarrow 4$ & $\mathrm{n}=4,4 \rightarrow 5$ & $\mathrm{n}=5,5 \rightarrow 6$ & $\mathrm{n}=6,6 \rightarrow 7$ & $\mathrm{n}=7,7 \rightarrow 8$ \\
\hline & $V_{\text {std }}^{n}[\mathrm{~km} / \mathrm{h}]$ & 15 & 35 & 50 & 70 & 90 & 110 & 130 \\
\hline \multirow{6}{*}{ All } & $V_{\text {GSL.avg }}^{n}[\mathrm{~km} / \mathrm{h}]$ & 15.9 & 29.4 & 44.1 & 59.7 & 83.5 & 83.0 & 108.3 \\
\hline & StDev & 2.7 & 4.0 & 5.2 & 7.7 & 16.3 & 10.8 & 25.1 \\
\hline & $\left|V_{\text {std }}^{n}-V_{\text {GSI.avg }}^{n}\right|$ & 0.9 & 5.6 & 5.9 & 10.3 & 6.5 & 27.0 & 21.7 \\
\hline & $\left|V_{\text {std }}^{n}-V_{\text {GSL.avg }}^{n}\right| \%$ & 6.0 & 16.0 & 11.8 & 14.7 & 7.2 & 24.5 & 16.7 \\
\hline & $V_{\text {GSI.min }}^{n}[\mathrm{~km} / \mathrm{h}]$ & 9.7 & 18.3 & 31.6 & 44.3 & 57.5 & 71.0 & 85.1 \\
\hline & $V_{\text {GSI.max }}^{n}[\mathrm{~km} / \mathrm{h}]$ & 23.4 & 37.3 & 58.8 & 77.4 & 125.2 & 98.1 & 140.0 \\
\hline \multirow{6}{*}{$\begin{array}{c}\text { MT } \\
\text { max } 6 \\
\text { speeds }\end{array}$} & $V_{\text {GSI.avg }}^{n}[\mathrm{~km} / \mathrm{h}]$ & 16.2 & 30.0 & 45.1 & 62.2 & 87.2 & - & - \\
\hline & StDev & 2.4 & 3.0 & 3.9 & 6.5 & 16.0 & - & - \\
\hline & $\left|V_{\text {std }}^{n}-V_{\text {GSI.avg }}^{n}\right|$ & 1.2 & 5.0 & 4.9 & 7.8 & 2.8 & - & - \\
\hline & $\mid V_{\text {std }}^{n}-V_{\text {GSI.avg }}^{n} / \%$ & 8.0 & 14.3 & 9.8 & 11.1 & 3.1 & - & - \\
\hline & $V_{\text {GSI.min }}^{n}[\mathrm{~km} / \mathrm{h}]$ & 12.2 & 24.4 & 38.2 & 50.3 & 60.8 & - & - \\
\hline & $V_{\text {GSI.max }}^{n}[\mathrm{~km} / \mathrm{h}]$ & 20.9 & 37.0 & 54.2 & 77.4 & 122.9 & - & - \\
\hline \multirow{6}{*}{$\begin{array}{c}\text { AT } \\
\text { max } 6 \\
\text { speeds }\end{array}$} & $V_{\text {GSI.avg }}^{n}[\mathrm{~km} / \mathrm{h}]$ & 16.0 & 29.6 & 43.4 & 56.6 & 85.2 & - & - \\
\hline & StDev & 1.8 & 3.7 & 6.4 & 6.8 & 15.1 & - & - \\
\hline & $\left|V_{\text {std }}^{n}-V_{\text {GSI.avg }}^{n}\right|$ & 1.0 & 5.4 & 6.6 & 13.4 & 4.8 & - & - \\
\hline & $\mid V_{\text {std }}^{n}-V_{\text {GSI.avg }}^{n} \%$ & 6.7 & 15.4 & 13.2 & 19.1 & 5.3 & - & - \\
\hline & $V_{\text {GSI.min }}^{n}[\mathrm{~km} / \mathrm{h}]$ & 14.0 & 25.0 & 36.9 & 50.0 & 72.1 & - & - \\
\hline & $V_{\text {GSI.max }}^{n}[\mathrm{~km} / \mathrm{h}]$ & 19.9 & 37.3 & 58.8 & 71.6 & 125.2 & - & - \\
\hline \multirow{6}{*}{$\begin{array}{c}\text { AT } 7 \\
\text { and } \\
8 \text { speeds }\end{array}$} & $V_{\text {GSI.avg }}^{n}[\mathrm{~km} / \mathrm{h}]$ & 14.5 & 25.5 & 39.8 & 51.6 & 65.2 & 83.0 & 108.3 \\
\hline & StDev & 4.8 & 6.5 & 6.2 & 7.2 & 5.8 & 10.8 & 25.1 \\
\hline & $\left|V_{\text {std }}^{n}-V_{\text {GSI.avg }}^{n}\right|$ & 0.5 & 9.5 & 10.2 & 18.4 & 24.8 & 27.0 & 21.7 \\
\hline & $\mid V_{\text {std }}^{n}-V_{\text {GSI.avg }}^{n} \%$ & 3.3 & 27.1 & 20.4 & 26.3 & 27.6 & 24.6 & - \\
\hline & $V_{\text {GSI.min }}^{n}[\mathrm{~km} / \mathrm{h}]$ & 9.7 & 18.3 & 31.6 & 44.3 & 57.5 & 71.0 & 85.1 \\
\hline & $V_{\text {GSI.max }}^{n}[\mathrm{~km} / \mathrm{h}]$ & 23.4 & 36.7 & 50.5 & 62.3 & 74.4 & 98.1 & 140.0 \\
\hline
\end{tabular}




\section{CONCLUSION}

Based on the presented results, GSI has obvious contribution to fuel economy (sample average saving is $5.2 \%$ and maximum is $19.9 \%$ ). Furthermore, fuel saving by choosing adequate gear shift points shows us that influence on driver behavior can provide an ecological benefit with minimum investment.

It can be concluded that standard gear shift points defined by type I emission test need to be revised. The question stands whether to look only after the recommendations given by GSI or to incorporate statistical analysis on how drivers follow these instructions. It is assumed (and it can be discussed) that the vehicle manufacturers are interested in getting the fuel consumption data using the tests that will take into account the GSI recommendations, in order to validate data on relative reduction of fuel consumption $F C_{\text {rel.save }}$. Mentioned analysis of driver behavior on given GSI indication can be regarded through his positive or negative reaction to GSI recommendations and, in the case of positive reaction, through time period needed for driver to react to the recommendation after the signal. This can be easily measured and should to be the subject of future investigation. It will show is it possible and to which extent to change the drivers' habits. In that sense, the possible improvement of GSI test procedure will make it more adequate.

\section{ACKNOWLEDGMENT}

This paper presents some of the results obtained through the project supported by Serbian Ministry of Education, Science and Technological Development (TR 35045 "Scientific-Technological Support to Enhancing the Safety of Special Road and Rail Vehicles").

\section{REFERENCES}

[1] European Commission: Commission Regulation (EU) No 65/2012 implementing Regulation (EC) No 661/2009 of the European Parliament and of the Council as regards gear shift indicators and amending Directive 2007/46/EC of the European Parliament and the Council, 2012.

[2] Groeger, J.A. and Clegg, B.A.: Automaticity and driving: Time to change gear conceptually, in: Carbonell, V.E. and Rothengatter, T. (Eds.): Traffic and Transport Psychology: Theory and Application, Pergamon Press, Oxford, 1997.

[3] Shinar, D., Meir, M. and Ben-Shoham, I.: How automatic is manual gear shifting? Hum. Factors, Vol. 40, No. 4, pp. 647-654, 1999.

[4] De Vlieger, I., De Keukeleere, D. and Kretzschmar, J.G.: Environmental effects of driving behaviour and congestion related to passenger cars, Atmos. Environ., Vol. 34, No. 27, pp. 4649-4655, 2000.
[5] Hooker, J.N.: Optimal driving for single-vehicle fuel economy, Transport. Res. A - Pol., Vol. 22A, No. 3, pp. 183-201, 1988.

[6] Van Mierlo, J., Maggetto, G., Van de Burgwal, E. and Gense, R.: Driving style and traffic measures influence on vehicle emissions and fuel consumption, P. I. Mech. Eng. D - J. Aut., Vol. 218, No. 1, pp. 43-50, 2004.

[7] National Research Council: Automobile fuel economy - How far should we go? National Academy Press, Washington D.C., 1992.

[8] Schindler, K.P.: Fuel savings by car, presented at the Strategies for promoting fuel saving on-board technologies - OPET workshop, Brussels, 2013.

[9] Blagojević, I.: Model for Multiparametric Gear Shifting Optimization in Motor Vehicle, PhD thesis, Faculty of Mechanical Engineering, University of Belgrade, Belgrade, 2009.

[10] Blagojević, I., Vorotović, G., Ivanović, G., Janković, S. and Popović, V.: Energy efficiency improvement by gear shifting optimization, Thermal Science, Vol. 17, No. 1, pp. 91-105, 2013.

[11] Van der Voort, M. et al.: A prototype fuelefficiency support tool, Transport. Res. D - Tr. E., Vol. 9, No. 4, pp. 279-296, 2001.

\section{АНАЛИЗА РЕЗУЛТАТА ИСПИТИВАҢА ИНДИКАТОРА ПРОМЕНЕ СТЕПЕНА ПРЕНОСА}

\section{И. Благојевић, Д. Стаменковић, Б. Ракићевић}

Анализирани су резултати добијени испитивањима према Правилнику (ЕУ) 65/2012, који се односи на индикаторе промене степена преноса, на 59 различитих возила. Основни параметри анализе су вредности брзине возила при којима индикатор препоручује промену степена преноса и њихова одступања од стандардних брзина у којима се мењају преносни односи у току испитивања издувне емисије према Тесту I УНЕЦЕ правилника број 83, при чему је закључено да стандардне брзине треба ревидирати. Анализиране су и релативне уштеде горива за случајеве промене степена преноса према индикатору и према стандардним брзинама (просечна 5,2\%, максимална 19,9\%). Такође, показано је да следећи препоруке индикатора, аутоматски мењачи у мануелном моду пружају могућност веће уштеде него мануелни мењачи. Закључено је да се статистичка анализа о томе у којој мери возачи поштују препоруке индикатора може искористити за унапређење тренутно важећих испитивања самих индикатора, потрошње горива и издувне емисије. 